\title{
A NEW SPECIES OF CHIASMOCLEIS (ANURA, MICROHYLIDAE) FROM THE ATLANTIC RAIN FOREST OF NORTHEASTERN BAHIA, BRAZIL
}

\author{
Author(s) :Carlos Alberto Gonçalves Cruz, Ulisses Caramaschi, Marcelo Felgueiras Napoli \\ Source: South American Journal of Herpetology, 2(1):47-52. 2007. \\ Published By: Brazilian Society of Herpetology \\ DOI: \\ URL: http://www.bioone.org/doi/full/10.2994/1808-9798\%282007\%292\%5B47\%3AANSOCA \\ $\% 5 \mathrm{D} 2.0 . \mathrm{CO} \% 3 \mathrm{~B} 2$
}

BioOne (www.bioone.org) is a nonprofit, online aggregation of core research in the biological, ecological, and environmental sciences. BioOne provides a sustainable online platform for over 170 journals and books published by nonprofit societies, associations, museums, institutions, and presses.

Your use of this PDF, the BioOne Web site, and all posted and associated content indicates your acceptance of BioOne's Terms of Use, available at www.bioone.org/page/terms_of_use.

Usage of BioOne content is strictly limited to personal, educational, and non-commercial use. Commercial inquiries or rights and permissions requests should be directed to the individual publisher as copyright holder. 


\title{
A NEW SPECIES OF CHIASMOCLEIS (ANURA, MICROHYLIDAE) FROM THE ATLANTIC RAIN FOREST OF NORTHEASTERN BAHIA, BRAZIL
}

\author{
Carlos Alberto Gonçalves Cruz ${ }^{1,3}$, Ulisses Caramaschi ${ }^{1}$ and Marcelo Felgueiras Napoli² \\ ${ }^{1}$ Museu Nacional/Universidade Federal do Rio de Janeiro, Departamento de Vertebrados, Quinta da Boa Vista, \\ São Cristóvão,20940-040 Rio de Janeiro,RJ,Brazil.E-mail: cagcruz@uol.com.br; ulisses@acd.ufrj.br \\ ${ }^{2}$ Instituto de Biologia, Museu de Zoologia, Universidade Federal da Bahia, Rua Barão de Geremoabo, \\ Campus Universitário de Ondina, 40170-290 Salvador,BA, Brazil.E-mail: napoli@ufba.br \\ ${ }^{3}$ Corresponding author: cagcruz@uol.com.br
}

\begin{abstract}
Aвstract: A new species of the genus Chiasmocleis is described from the Reserva Sapiranga, an Atlantic Rain Forest remnant in the Municipality of Mata de São João, northeastern State of Bahia, Brazil. This species belongs to the C. leucosticta group, characterized by well-developed webbing on feet. Chiasmocleis sapiranga sp. nov. is diagnosed by having the fingers extensively fringed in males and only slightly fringed in females, and by the dorsal region uniformly dark brown and ventral region finely marbled in brown and pale cream.
\end{abstract}

Keywords: Amphibia. Anura. Microhylidae. Chiasmocleis sapiranga sp. nov. Atlantic Rain Forest. Bahia.

INTRODUCTION

The genus Chiasmocleis, proposed by Méhelÿ (1904) for Chiasmocleis albopunctata (Boettger, 1885), currently comprises 19 recognized species: one species occurs in Panama; six species in northern South America, associated with the Amazon Forest; three species inhabit open areas or "cerrados" of central and southeastern Brazil and adjacent countries; and nine species occur in eastern Brazil, associated with the Atlantic Rain Forest, from the State of Alagoas to Santa Catarina (Caramaschi and Cruz, 1997; Cruz et al., 1997; Cruz et al., 1999; Caramaschi and Cruz, 2001; Canedo et al., 2004). Based on the degree of webbing on the feet, Cruz et al. (1997) and Cruz et al. (1999) divided the Atlantic Rain Forest species of Chiasmocleis into two morphologically distinct groups. The first group comprised species with well developed webbing - C. leucosticta (Boulenger, 1888), C. capixaba Cruz, Caramaschi and Izecksohn, 1997, C. cordeiroi Caramaschi and Pimenta, 2005, and C. crucis Caramaschi and Pimenta, 2005; the second group included species with only vestigial or no webbing - C. schubarti Bokermann, 1952, C. atlantica Cruz, Caramaschi and Izecksohn, 1997, C. carvalhoi Cruz, Caramaschi and Izecksohn, 1997, C. alagoana Cruz, Caramaschi and Freire, 1999, and C. gnoma Canedo, Dixo and Pombal, 2004.

Herein we describe a new species belonging to the C. leucosticta group that was collected during a survey of amphibians in a private property named Reserva Sapiranga, Municipality of Mata de São João, northern coastline of the State of Bahia, Brazil.

\section{Material And Methods}

Type-specimens are deposited at the Museu Nacional, Rio de Janeiro, RJ, Brazil (MNRJ) and Museu de Zoologia, Universidade Federal da Bahia, Salvador, BA, Brazil (UFBA). Additional specimens examined are listed in the Appendix. Measurements, in millimeters, are: SVL (snout-vent length); HL (head length); HW (head width); IND (internarial distance); END (eye to nostril distance); ED (eye diameter); UEW (upper eyelid width); IOD (interorbital distance); THL (thigh length); TL (tibia length); FL (foot length, including tarsus and foot).

\section{RESULTS}

Chiasmocleis sapiranga sp. nov.

(Figs. 1-5)

Holotype-UFBA 4986, adult male, collected at Reserva Sapiranga (12 $34^{\circ} \mathrm{S}$; $38^{\circ} 02^{\prime} \mathrm{W}, 12 \mathrm{~m}$ altitude), Municipality of Mata de São João, State of Bahia, Brazil, 02-04 May 2005, collected by C.V. Bastazini, A. Camacho, M. Camardelli, and T.F.S.S.A. Santos.

Paratopotypes-MNRJ 41850-41851, adult males, MNRJ 41852-41853, adult females, and UFBA 4981, 4983-4984, adult females, collected with the holotype.

Diagnosis - A medium sized species of Chiasmocleis diagnosed by the following combination of character states: (1) SVL 19.0-20.9 mm in males, 21.2-25.0 mm in females; (2) body trunk ovoid; (3) snout short, tip 
rounded in dorsal and lateral profiles; (4) hand not webbed in males and females, foot webbed in males and one third webbed in females; (5) fingers and toes lacking disks, fingers extensively fringed in males and only slightly fringed in females; (6) fingers and toes with few small lateral dermal spines in males; (7) dorsal surfaces with numerous small dermal spines in males; (8) in preservative, dorsum dark brown with

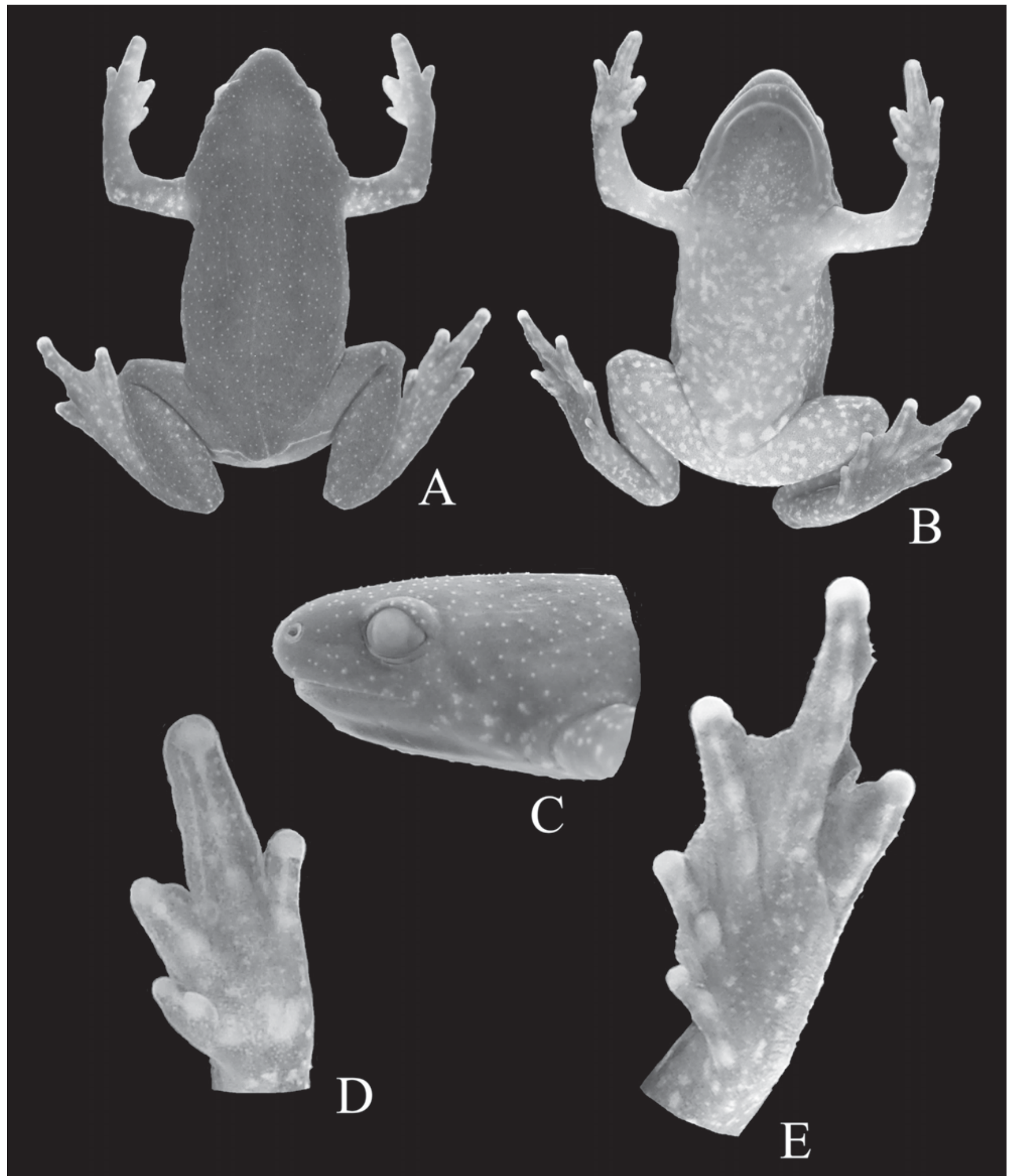

Figure 1: Chiasmocleis sapiranga sp. nov. (holotype, UFBA 4986, SVL 20.9 mm). (A) Dorsal view. (B) Ventral view. (C) Lateral profile of head. (D) Hand. (E) Foot. 
a whitish longitudinal mid-dorsal line; (9) posterior sides of legs with a whitish longitudinal line; (10) venter finely marbled dark brown and pale cream.

Comparison with other species - Among the Atlantic Rain Forest species of Chiasmocleis, the presence of well-developed webbing on feet of males differentiates $C$. sapiranga sp. nov. from C. alagoana, C. atlantica, C. carvalhoi, C. gnoma, and C. schubarti, in which foot webbing is absent (Canedo et al., 2004; Cruz et al., 1997; Cruz et al., 1999), and associates the new species with C. capixaba, C. cordeiroi, C. crucis, and C. leucosticta (Cruz et al., 1997; Caramaschi and Pimenta, 2003). The presence of extensively developed fringing on male fingers distinguishes $C$. sapiranga sp. nov. from C. capixaba, C. cordeiroi, and C. crucis (fringes less developed). Chiasmocleis sapiranga sp. nov. has a foot length that is approximately $65 \%$ of the snout-vent length in males (C. capixaba $66 \%$, C. cordeiroi $45 \%$, C. crucis $47 \%$, and $C$. leucosticta $67 \%$ ). The new species is distinguished from C. capixaba in having an uniformly dark brown dorsal region (dorsum grayish brown with gray blotches irregularly distributed in C. capixaba) and adult male snout-vent length ranging from 19.0 to $20.9 \mathrm{~mm}$ (SVL $14.7-16.5 \mathrm{~mm}$ in C. capixaba adult males); from C.crucis, the new species is separated by the presence of well developed (i.e., more than half) webbing on feet in males (feet approximately half webbed in males of C. crucis), and from C. leucosticta the new species is distinguished by having the ventral region finely marbled dark brown and pale cream (ventral region brown with irregular and disperse pale cream blotches in C. leucosticta) (Cruz et al., 1997; Caramaschi and Pimenta, 2003).
Description - Summary statistics are provided in Table 1. Size moderate for the genus (SVL 19.0-20.9 $\mathrm{mm}$ in males, 21.2-25.0 $\mathrm{mm}$ in females); body trunk ovoid (Fig. 1A-B); head short, slightly broader than long; nostrils at the tip of snout, not protuberant, directed laterally; snout short, tip rounded in dorsal (Fig. 1A) and lateral profiles (Fig. 1C); internarial distance smaller than eye to nostril distance and only slightly larger than eye diameter; eye diameter less than eye to nostril distance; canthus rostralis not defined; loreal region oblique, flat; lips not flared; eyes small, only slightly protruding; upper eyelid width equal to one third of the interorbital space; interorbital area flat; cranial crests and occipital fold absent; postorbital fold present; tympanum absent; upper jaw projecting beyond lower; mandible with truncate, trilobed anterior margin; tongue large, ovoid; choanae small, rounded, widely separated; vocal sac, small, subgular.

Arms slender, lacking tubercles and crests on forearm. Hand of male (Fig. 1D) and female not webbed; fingers lacking disks and extensively fringed in males, only slightly fringed in females, and with lateral dermal spines in males; finger lengths $\mathrm{I}<\mathrm{II}<\mathrm{IV}<\mathrm{III}$; subarticular tubercles well developed, rounded; supernumerary tubercles absent; palmar tubercle large, divided in two parts; thenar tubercle large, rounded, at the base of finger I.

Legs short, robust; knee and heel lacking tubercles; tibial and tarsal ridges absent. Foot of males (Fig. 1E) extensively webbed whereas that of females only one third webbed; toes with fringes on non-webbed portions; toes lacking disks; toe lengths $\mathrm{I}<\mathrm{II}<\mathrm{V}<\mathrm{III}<\mathrm{IV}$; toes with few small lateral dermal spines in males, absent in females; subarticular tubercles well devel-

TABLE 1: Summary statistics for Chiasmocleis sapiranga sp. nov. (n, number of specimens; $\chi$, mean; SD, standard deviation).

\begin{tabular}{|c|c|c|c|c|c|c|}
\hline \multirow[b]{2}{*}{ Measurements } & \multicolumn{3}{|c|}{ Males $(\mathrm{n}=3)$} & \multicolumn{3}{|c|}{ Females $(\mathrm{n}=5)$} \\
\hline & Range & $\chi$ & $\mathrm{SD}$ & Range & $\chi$ & $\mathrm{SD}$ \\
\hline SVL & $19.0-20.9$ & 19.9 & 0.95 & $21.2-25.0$ & 23.5 & 1.44 \\
\hline HL & $4.6-5.5$ & 5.0 & 0.47 & $5.3-6.0$ & 5.7 & 0.27 \\
\hline HW & $5.7-5.9$ & 5.8 & 0.10 & $6.1-6.7$ & 6.4 & 0.24 \\
\hline IND & $1.2-1.4$ & 1.3 & 0.11 & $1.5-1.7$ & 1.60 & 0.08 \\
\hline END & $1.3-1.5$ & 1.4 & 0.10 & $1.5-1.8$ & 1.7 & 0.12 \\
\hline $\mathrm{ED}$ & $1.3-1.4$ & 1.4 & 0.06 & $1.3-1.5$ & 1.4 & 0.07 \\
\hline UEW & $0.7-1.0$ & 0.8 & 0.15 & $0.9-1.1$ & 1.0 & 0.08 \\
\hline IOD & $2.7-2.9$ & 2.7 & 0.11 & $3.0-3.7$ & 3.3 & 0.30 \\
\hline THL & $8.4-8.5$ & 8.5 & 0.06 & $9.2-9.7$ & 9.5 & 0.18 \\
\hline $\mathrm{TL}$ & $8.0-8.4$ & 8.1 & 0.23 & $9.0-9.7$ & 9.5 & 0.28 \\
\hline FL & $12.9-13.3$ & 13.0 & 0.21 & $13.8-14.4$ & 14.1 & 0.28 \\
\hline
\end{tabular}


oped, ovoid; supernumerary tubercles absent; an oval inner, but no outer, metatarsal tubercle. Thigh length slightly longer than tibia length; knee and elbow widely separated with limbs adpressed to sides of body; combined thigh and tibia lengths approximately $83 \%$ of snout-vent length in males, $80 \%$ in females; heels slightly overlapping when flexed legs held at right angles to body; foot length approximately $65 \%$ of snout-vent length in males, $60 \%$ in females.

Skin smooth above and beneath; dorsal and ventral surfaces of body and limbs with numerous small, uniformly distributed dermal spines in males, absent in females, except around the cloacal opening.

Color in preservative - Dorsum dark brown with a whitish longitudinal mid-dorsal line; another whitish longitudinal line present on the posterior sides of legs. Venter marbled dark brown and pale cream; male throat infuscate.

Measurements of holotype - SVL 20.9; HL 5.5; HW 5.9; IND 1.2; END 1.3; ED 1.3; UEW 0.7; IOD 2.9; THL 8.5; TL 8.4; FL 13.2.

Etymology - The name of the species, "sapiranga", a noun in apposition, refers to the type locality.

Habitat and natural history - The Reserva Sapiranga can be characterized as a "restinga" forest. The "restingas" are restricted to the Atlantic Forest Biome and are typically known as coastal sand dune habitats, covered with herbaceous and shrubby vegetation, and they are common along the Brazilian coastline. The Reserva Sapiranga includes 500 hectares covered by arboreal vegetation, with various water sources available such as springs, streams, freshwater and brackish rivers, lakes, ponds, as well as areas without bodies of water with a few terrestrial bromeliads $(\mathrm{N}<20$ bromeliads per $1000 \mathrm{~m}^{2}$ ), and sandy areas without bodies of water with a high density of bromeliads $(\mathrm{N}>100$ bromeliads per $1000 \mathrm{~m}^{2}$ ). Specimens of $C$. sapiranga sp. nov. were only collected in pitfall-traps (20-liter plastic buckets with 2-drift fence array, each fence $5 \mathrm{~m}$ long and $50 \mathrm{~cm}$ high), although we also employed 84 hours of active searching at night, uniformly distributed over three sampling periods (06-13 September 2004, 25 April to 02 May 2005, and 16-23 August 2005). The specimens were collected in plots with (1) arboreal vegetation with temporary ponds and/or permanent lakes, (2) arboreal vegetation with rivers, springs or streams, and (3) arboreal vegetation without bodies of water on the ground; however, they seem to occur more commonly in the latter two environments. Further datails on the ecology and biology of $C$. sapiranga sp. nov. are unavailable.

\section{RESUMO}

Uma nova espécie do gênero Chiasmocleis é descrita da Reserva de Sapiranga, um remanescente de Floresta Atlântica no Município de Mata de São João, nordeste do Estado da Bahia, Brasil. A nova espécie pertence ao grupo de C. leucosticta, que é caracterizado pela presença de membranas interdigitais bem desenvolvidas nos pés. Chiasmocleis sapiranga sp. nov. é diagnosticada por apresentar os dedos das mãos extensivamente fimbriados nos machos e apenas ligeiramente fimbriados nas fêmeas, com a região dorsal uniformemente marrom-escuro e a ventral finamente marmoreada de marrom e creme claro.

\section{ACKNOWLEDGMENTS}

We are grateful to Agustín C. Guerrero, Ariane L. Xavier, Camila V. Baztazini, Milena Camardelli, Patricia M. Fonseca, Rafael O. Abreu, Tatiane Brandão, and Thales F. S. S. A. Santos for the field assistance. The Fundação Garcia D'Ávila and A. A. Paiva allowed us access to research areas under their care and provided logistical assistance at Reserva Sapiranga. We thank José P. Pombal Jr. and Bruno V. S. Pimenta for critically reviewing the manuscript. The Instituto Brasileiro do Meio Ambiente e dos Recursos Naturais Renováveis (IBAMA) permitted collection of specimens (licenses numbers 02006.002336/03-26 and $0210.000812 / 05-84$ ). This work was partially supported by grants from the CNPq (Conselho Nacional de Desenvolvimento Científico e Tecnológico).

\section{Literature Cited}

Canedo, C., M. Dixo, and J. P. Pombal, Jr. 2004. A new species of Chiasmocleis Méhelÿ, 1904 (Anura, Microhylidae) from the Atlantic Rainforest of Bahia, Brazil. Herpetologica, 60:495-501.

Caramaschi, U. and C. A. G. Cruz. 1997. Redescription of Chiasmocleis albopunctata (Boettger) and description of a new species of Chiasmocleis (Anura: Microhylidae). Herpetologica, 53:259-268.

Caramaschi, U. and C. A. G. Cruz. 2001. A new species of Chiasmocleis Méhelÿ, 1904 from Brazilian Amazonia (Amphibia, Anura, Microhylidae). Boletim do Museu Nacional, Nova Série, Zoologia, 469:1-8.

Caramaschi, U. and B. V. S. Pimenta. 2003. Duas novas espécies de Chiasmocleis Méhelÿ, 1904 da Mata Atlântica do Sul da Bahia, Brasil (Amphibia, Anura, Microhylidae). Arquivos do Museu Nacional, 61: 195-202.

Cruz, C. A. G., U. Caramaschi and E. Izecksohn. 1997. The genus Chiasmocleis Méhelÿ, 1904 (Anura, Microhylidae) in the Atlantic Rain Forest of Brazil, with description of three new species. Alytes, 15:49-71. 
Cruz, C. A. G., U. Caramaschi, and E. M. X. Freire. 1999. Occurrence of the genus Chiasmocleis (Anura: Microhylidae) in the State of Alagoas, north-eastern Brazil, with a description of a new species. Journal of Zoology, 249:123-126.
MéHelŸ, L. V. 1904. Investigations on Paraguayan batrachians. Annales Musei Nationalis Hungarici, 2:207-232.

Submitted 11 November 2006 Accepted 20 February 2007 
APPENDIX

Additional specimens examined

Chiasmocleis alagoana: BRASIL - ALAGOAS: Maceió (MNRJ 21856, holotype; MNRJ 21857); Rio Largo (MNRJ 21858, 21859, 21860-21861, paratypes).

Chiasmocleis atlantica: BRASIL - RIO DE JANEIRO: Nova Iguaçu (MNRJ 17550, holotype; MNRJ 17549, 17551-17554, paratypes).

Chiasmocleis capixaba: BRASIL - ESPÍRITO SANTO: Aracruz (MNRJ 17514, holotype; MNRJ 17515-17529, 17532-17534, 17535-17537, 17891-17895, paratypes); Cariacica (MNRJ 27896-27904, 27907); Linhares (MNRJ 22962-22966, 29057-29060, 29073-29074).

Chiasmocleis carvalhoi: BRASIL - BAHIA: Mucuri (MNRJ 19380-19381); Porto Seguro (MNRJ 28960-28961); Una (MNRJ 28605-28624). RIO DE JANEIRO: Seropédica (MNRJ 17505, holotype; MNRJ 17480-17490, 17492, 17498, 17500-17503, 17565, paratypes); Niterói (MNRJ 17577-17578).

Chiasmocleis cordeiroi: BRASIL - BAHIA: Camamu (MNRJ 29931, holotype; MNRJ 29932, paratype).

Chiasmocleis crucis: BRASIL - BAHIA: Camamu (MNRJ 29933, holotype; MNRJ 29934-29938, paratypes).

Chiasmocleis gnoma: BRASIL-BAHIA: Una(MNRJ 28628, holotype; MNRJ 28629-28630, 28632, 32621-32626, 32628-32630, 32631-32632, 32635, 32638, 32643-32644, paratypes).

Chiasmocleis leucosticta: BRASIL - SÃO PAULO: Casa Grande (MNRJ 17564); Ilha Bela (MNRJ 23663); Ribeirão Branco (MNRJ 17900-17904). SANTA CATARINA: Corupá (MNRJ 0525, 5582, syntypes of Nectodactylus spinulosus); Santa Luzia e Araújos (MNRJ 17563).

Chiasmocleis schubarti: BRASIL - BAHIA: Guaratinga (MNRJ 29773); Porto Seguro (MNRJ 27256, 28875, 28894-28897, 28957-28959, 28962); Prado (MNRJ 28907-28908); Una (MNRJ 28585-28604). ESPÍRITO SANTO: Aracruz (MNRJ 17538-17547, 17896-17899); Cariacica (MNRJ 27894-27895, 27905-27906); Linhares (MNRJ 17548, 22959-22961, topotypes). 